\title{
Changing Tides: Tax Haven Reform and the Changing Views of Transnational Capital Flow Regulation and the Role of States in a Globalized World
}

Jeffrey Kraft

Indiana University Maurer School of Law, jemkraft@indiana.edu

Follow this and additional works at: https://www.repository.law.indiana.edu/ijgls

Part of the Banking and Finance Law Commons, International Law Commons, Law and Economics Commons, Taxation-Transnational Commons, and the Tax Law Commons

\section{Recommended Citation}

Kraft, Jeffrey (2014) "Changing Tides: Tax Haven Reform and the Changing Views of Transnational Capital Flow Regulation and the Role of States in a Globalized World," Indiana Journal of Global Legal Studies: Vol. 21 : Iss. 2 , Article 8.

Available at: https://www.repository.law.indiana.edu/ijgls/vol21/iss2/8

This Note is brought to you for free and open access by the Law School Journals at Digital Repository @ Maurer Law. It has been accepted for inclusion in Indiana Journal of Global Legal Studies by an authorized editor of Digital Repository@Maurer Law. For more information, please contactrvaughan@indiana.edu.

\section{$\Psi$}

JEROME HALL LAW LIBRARY

INDIANA UNIVERSITY

Maurer School of Law
Blooming ton 


\title{
Changing Tides: Tax Haven Reform and the Changing Views on Transnational Capital Flow Regulation and the Role of States in a Globalized World
}

\author{
JEFFREY KRAFT ${ }^{*}$
}

ABSTRACT

The transnational free flow of capital represents one of the core factors driving the globalization of the world since the beginning of the Bretton-Woods era. Under the "traditional" Neoliberal theory of globalization, this free flow of capital remains sacrosanct, an unstoppable force with which state actors cannot and should not interfere. However, the recent financial crisis has caused some to question this absolute faith in the benefits of unregulated transnational capital flows and to assert that the state still has a role to play in influencing the creation of international norms on capital. Tax haven regulation represents one area that has seen a significant increase in interest in the United States since the financial crisis, most notably in the forms of the Stop Tax Haven Abuse Act and the Foreign Account Tax Compliance Act. Although much has already been written on the purported benefits and drawbacks of tax haven reform, this note will instead focus on the view of globalization and the state's role in it that underlie these pieces of legislation. In short, this note will argue that this legislation, and the renewed interest in tax haven regulation surrounding it, represents a shift away from the absolutist neoliberal view of globalization toward one that both recognizes the potential benefits of capital-flow regulation and the ability of state actors to use their domestic law-making capacity to influence the creation of these new international regulatory norms.

* Executive Production Editor, Indiana Journal of Global Legal Studies; J.D. Candidate, 2014, Indiana University Maurer School of Law; B.A., 2010, University of Notre Dame.

Indiana Journal of Global Legal Studies Vol. 21 \#2 (Summer 2014)

(c) Indiana University Maurer School of Law 


\section{INTRODUCTION}

The 2008 financial crisis has led to widespread rethinking of national and transnational financial norms. ${ }^{1}$ Indeed, these restructuring efforts have proven so substantial that some have labeled them collectively as a second "Bretton Woods," referring to the 1944 Bretton-Woods Conference that led to the establishment of many of the global financial norms in the post-war era. ${ }^{2}$ These efforts at global financial reform have included a renewed interest in regulating socalled tax havens. ${ }^{3}$ Tax havens are generally defined as "any country that does not seek to attract real investment, but instead promotes tax evasion to attract and increase foreign capital held in its jurisdiction through the use of lenient tax laws and strict bank secrecy."4 Interestingly, these attempts at transnational tax haven reform have occurred not just at the international level but at the national level as well. For example, efforts in the U.S. Congress led to the introduction of two pieces of legislation aimed at dealing with the perceived negative impacts of tax havens: the Stop Tax Haven Abuse Act, originally introduced in $2007^{5}$ and reintroduced in $2009,{ }^{6} 2011,{ }^{7}$ and $2013,{ }^{8}$ and the Foreign Account Tax Compliance Act (FATCA), originally introduced in $2009^{9}$ and enacted as part of the Hiring Incentives to Restore Employment Act. ${ }^{10}$

The Stop Tax Haven Abuse Act, originally cosponsored by thensenator Barack Obama,11 seeks to combat the veil of secrecy surrounding tax havens through the implementation of four rebuttable presumptions:

1. See David Spencer, Cross Border Tax-Evasion and Bretton Woods II (Part 1), J. INT'L TAX'N, May 2009, at 44, 45.

2. Id. at 46 .

3. See id. at $45-46$.

4. Timothy V. Addison, Shooting Blanks: The War on Tax Havens, 16 IND. J. GLOBAL LEGAL STUD. 703, 706 (2009).

5. Stop Tax Haven Abuse Act, S. 681, 110th Cong. (2007); Stop Tax Haven Abuse Act, H.R. 2136, 110th Cong. (2007).

6. Stop Tax Haven Abuse Act, S. 506, 111th Cong. (2009); Stop Tax Haven Abuse Act, H.R. 1265, 111th Cong. (2009).

7. Stop Tax Haven Abuse Act, S. 1346, 112th Cong. (2011); Stop Tax Haven Abuse Act, H.R. 2669, 112th Cong. (2011).

8. Stop Tax Haven Abuse Act, H.R. 1554, 113th Cong. (2013); Stop Tax Haven Abuse Act, S. 1533, 113th Cong. (2013); Sequester Delay and Stop Tax Haven Abuse Act, H.R. 3666, 113th Cong. (2013).

9. Foreign Account Tax Compliance Act, S. 1934, 111th Cong. (2009).

10. Hiring Incentives to Restore Employment Act, H.R. 2847, 111th Cong. (2010).

11. Bruce Zagaris, Stop Tax Haven Abuse Act Reintroduced in U.S. Congress, 25 INT'L ENFORCEMENT L. REP. 237 (2009). 
(1) Control-if in a tax proceeding a U.S. person (other than a publicly traded corporation) directly or indirectly, formed, transferred assets to, and was a beneficiary of, or received distributions from an OSJ [Offshore Secrecy Jurisdictions] entity, it will be presumed that the person exercised control over the entity.

(2) Transfers of income-in a tax proceeding any amount or thing of value transferred to a U.S. person (other than a publicly traded corporation) directly or indirectly from an account or entity in an OSJ, or transferred from such a U.S. person directly or indirectly to an account or entity in an OSJ, will be presumed to represent previously unreported income to the U.S. person in the year of transfer.

(3) Beneficial ownership-In a proceeding to enforce securities law, if a U.S. person (other than a publicly traded corporation) formed, transferred assets to, or benefitted from an OSJ entity (other than a publicly traded corporation), it will be presumed that the person beneficially owned and exercised control over such entity, regardless of the nominal ownership.

(4) Foreign financial accounts-In lieu of the current law requiring U.S. taxpayers to report (on the Foreign Bank Account Report) to the IRS any foreign financial account containing at least $\$ 10,000$, the bill establishes a presumption that any account in an OSJ has funds sufficient to trigger this reporting requirement. ${ }^{12}$

The Act also provides for a public list of known tax havens that the Secretary of the Treasury may update after determining that a jurisdiction's rules and regulations prevent the United States from gaining the information necessary to enforce its tax laws. ${ }^{13}$ Finally, the Act would strengthen enforcement standards by authorizing the U.S.

12. Id.

13. Id. (naming Anguilla, Antigua and Barbuda, Aruba, Bahamas, Barbados, Belize, Bermuda, British Virgin Islands, Cayman Islands, Cook Islands, Costa Rica, Cyprus, Dominica, Gibraltar, Grenada, Guernsey/Sark/Alderney, Hong Kong, Isle of Man, Jersey, Latvia, Liechtenstein, Luxembourg, Malta, Nauru, Netherlands Antilles, Panama, Samoa, St. Kitts and Nevis, St. Lucia, St. Vincent and the Grenadines, Singapore, Switzerland, Turks and Caicos, and Vanuatu as known tax havens). 
Treasury to impose various sanctions against tax havens and financial institutions that use its services, by requiring more stringent disclosure requirements of banks and securities who have U.S. taxpayers as beneficial owners of their foreign-owned accounts, by increasing the amount of time allowed for investigating a tax return involving tax havens, by placing stricter requirements on U.S. beneficiaries of foreign trusts, and by increasing the penalty for failing to disclose offshore interests, among other provisions. ${ }^{14}$

FATCA, although similar in its goal of combating offshore tax evasion, focuses more primarily on strengthening reporting requirements. ${ }^{15}$ Specifically, FATCA provides for a 30 percent tax withholding on payments either to foreign banks and trusts that fail to disclose U.S. accounts or to foreign corporations who fail to disclose U.S. interest holders, requires disclosure by U.S. persons of a variety of interests in a foreign entity, and broadens the definition of who qualifies as a U.S. beneficiary of a foreign trust requiring disclosure. ${ }^{16}$ FATCA also imposes stiff monetary penalties against U.S. persons who fail to make these required disclosures of foreign-held assets and interests. ${ }^{17}$

The policy merits of these two pieces of legislation and tax haven regulation in general have already been debated at length. ${ }^{18}$ Indeed, there remains little consensus on even the precise definition of "tax haven." 19 However, this note will not address the technical merits of these two pieces of legislation; rather, this note will examine this legislation in light of the theories of globalization it embodies. Admittedly, political and pragmatic concerns played a much more overt role in the creation of these pieces of legislation, and neither embodies any theory of globalization explicitly or completely. Furthermore, the globalization theories this note will argue underlie the recent tax-haven reform efforts predate both these reform efforts and the financial crisis; neither the financial crisis nor tax haven reform can take credit for their

14. Id.

15. See Bruce Zagaris, U.S. Enacts Foreign Account Tax Compliance Act, 26 INT'L ENFORCEMENT L. REP. 193 (2010).

16. Id.

17. $I d$.

18. See, e.g., Susan C. Morse, Tax Compliance and Norm Formation under HighPenalty Regimes, 44 CoNN. L. REV. 675, 727-28 (2012) (critiquing FATCA); Maria Tihin, The Trouble with Tax Havens: The Need for New Legislation in Combating the Use of Offshore Trusts in Abusive Tax Shelters, 41 ColuM. J.L. \& Soc. PROBS. 417, 432-36 (2008) (critiquing the Stop Tax Haven Abuse Act).

19. See Addison, supra note 4, at 705-06 (noting that, based on different factors used, compiled lists of states designated as tax havens can vary greatly); Tihin, supra note 18 , at 421 (stating that a "very fine line" divides legitimate tax shelters favored by the legislature and tax laws from abusive tax shelters whose services circumvent the tax laws). 
introduction into globalization scholarship. This note will seek to show how this legislation, as a response to the recent financial crisis, reflects a limited shift in the prevailing view of globalization from one with the untouchable free flow of capital at its core toward one where states can positively influence the creation of new transnational capital norms. To that end, Part I will first provide an overview of the "traditional" neoliberal theory of globalization, with its emphasis on the primacy of the market and capital mobility, and will discuss how the traditional view of tax havens reflected this worldview. Part II will then examine emerging alternate theories of globalization that question the sanctity of unregulated capital flows and allow for an active role for state and nonstate actors in influencing international norm creation. Finally, Part III will analyze the scholarship and legislative history surrounding both FATCA and the Stop Tax Haven Abuse Act in light of these changing views of globalization.

\section{NEOLIBERAL GLOBALIZATION THEORY AND CAPITAL MOBILITY}

Until the recent financial crisis, the neoliberal theory of globalization represented the dominant globalization worldview behind both national and transnational financial policymaking. ${ }^{20}$ The neoliberal view finds its origins in the 1944 Bretton-Woods Conference, an event that, much like the current efforts to combat the 2008 financial crisis, sought to redefine transnational financial structures and norms in the wake of a massive systemic upheaval. ${ }^{21}$ This view of globalization has two principle characteristics: the primacy of market forces over state sovereignty ${ }^{22}$ and the unrestricted transnational flow of capital. ${ }^{23}$

\section{A. Rule of the Market}

As Susan Strange notes, the erosion of state authority in favor of the impartial and uncontrollable rule of the global market economy lies at the core of the neoliberal theory of globalization:

20. See Gopal Balakrishnan, The Twilight of Capital?, in IMMANUEL WALLERSTEIN AND THE PRoblem of THE World: SyStem, SCALE, Culture 227, 228 (David Palumbo-Liu et al. eds., 2011) (noting the dominance of the Neo-Liberal view of globalization from end of the Cold War to the start of the recent financial crisis).

21. Spencer, supra note 1 , at 46 .

22. Susan Strange, The Declining Authority of States, in THE GLOBAL TRANSFORMATIONS READER: AN INTRODUCTION TO THE GLOBALIZATION DEBATE 127, 128 (James N. Rosenau, ed. 2003).

23. See id. at 132 (asserting that the increasing costs of new technologies could not have been covered without the increased capital mobility that has accompanied globalization). 
The argument put forward is that the impersonal forces of world markets, integrated over the postwar period more by private enterprise in finance, industry[,] and trade than by the cooperative decisions of governments, are now more powerful than the states to whom ultimate political authority over society and economy is supposed to belong. ${ }^{24}$

Strange, like other proponents of neoliberal view, cites several factors in support of this worldview. To begin with, Strange points to the fact that states have failed to provide many of the "fundamentals," such as "security against violence, stable money for trade and investment, a clear system of law and the means to enforce it, and a sufficiency of public goods like drains, water supplies, infrastructure for transport and communications," that most associate with the just exercise of state authority. ${ }^{25}$ These failings, Strange claims, have eroded popular respect for the traditional authority of states. ${ }^{26}$ Furthermore, Strange argues that many states have only aided the decay of their authority by increasing government regulation in "marginal" matters such as product safety and transportation systems, actions that she claims only serve to "trivialize] government" and further erode popular respect for traditional state authority. ${ }^{27}$

The second and related factor Strange points to is the increasingly rapid technological evolution that has occurred during the last century. ${ }^{28}$ The effect of this technological advancement proved twofold. First, the dramatic increase in the destructiveness of weapons technology has contributed to the erosion of public confidence in the ability of state governments to defend their citizens. ${ }^{29}$ Second, and perhaps most important, the rapid proliferation of civilian technology provided the catalyst for the creation of a consumer-driven, global, capitalist economy in which gaining market share, not territory, brings wealth and power. ${ }^{30}$ Strange claims that Germany and Japan provide the best proof of this. Although both lost tremendous amounts of territory after World War II, both states rapidly rose to positions of power on the world stage, not through military might and capture of

24. Id. at 128 .

25. Id.

26. Id.

27. Id.

28. Id. at 130 .

29. See id. (asserting that the rise of nuclear weapons technology has eroded "one of the primary reasons for the existence of the state[-]its capacity to repel attack by others").

30. Id. at 131. 
territory, but through economic might and the capture of market share. ${ }^{31}$ Because this economic power comes largely through the private rather than public sector, transnational corporations and other private actors have replaced many state governments as the choicest allies for actors seeking to increase their economic power ${ }^{32}$ In short, although states have become economically powerful under this neoliberal view of globalization, they owe that power not to their traditional authority as states, but to market forces beyond their control. ${ }^{33}$ They exist merely as ships adrift on the impartial sea of the market. ${ }^{34}$

\section{B. Unrestricted Transnational Flows of Capital}

Along with emphasizing the importance of market forces over state authority, proponents of the neoliberal theory of globalization also promote the importance of the unrestricted transnational flow of capital, which they claim "eliminates much inefficiency[,] . . applies capital wherever it brings the highest returns[,] . . . disciplines lazy management[,] and ... offers far better opportunities for managing risks." 35 According to Strange, the aforementioned rapid advancement has created a major need for unfettered capital mobility: as technology has advanced, the capital costs for increased advancement have increased in kind. ${ }^{36}$ Consequently, increased capital mobility is required to maintain the increased wealth and power that technologic advancement has afforded the global market economy. ${ }^{37}$

These principles of the neoliberal theory of globalization underlie previous regulation of tax havens (or lack thereof). Proponents of this view of globalization recognize the legitimate use of tax havens as just another example of efficient use of capital resulting from unfettered transnational capital mobility. ${ }^{38}$ Consequently, earlier domestic attempts to limit or control the flow of capital to or from tax havens, such as the U.S. Revenue Act of 1962, the Tax Reduction Act of 1975, and the Tax Reform Act of 1986, have witnessed stringent opposition

31. Id.

32. Id.

33. Id. at 132-33 (asserting that "power . . . is exercised impersonally by markets and often unintentionally by those who buy and sell and deal in markets").

34. Id. at 133 (referring to state actors as "victims of the market economy").

35. David Spencer \& J.C. Sharman, International Tax Cooperation (Part 1), 18 J. INT'L TAX'N 34, at 35 (2007) (quoting Why Finance Will Not Be Unfettered, FinanCIAL TIMES, June 25,2007 , at 10 ).

36. Strange, supra note 22 , at 132 .

37. Id.

38. Walter H. Diamond et al., TAX HAVENS OF THE WORLD INT-1 (2012). 
and have proven largely ineffective..$^{39}$ Multinational efforts have proven ineffective too, as the failure of the Organisation of Economic Cooperation and Development's (OECD) "name and shame" campaign against tax havens makes clear. ${ }^{40}$ Indeed, significant opposition toward tax haven reform exists today, opposition still based on protecting the unimpeded transnational flow of capital. ${ }^{41}$

\section{Emerging Alternative Theories of Globalization}

Although still relevant, the preeminence of the neoliberal theory of globalization has waned in the wake of the recent financial crisis, with alternative theories emerging to challenge its long-held assumptions about globalization. Two theories prove particularly relevant to this note: Peter Evans's "counter-hegemonic globalization" 42 and Harold Koh's "transnational legal process." 43

\section{A. Counter-Hegemonic Globalization}

Peter Evans's alternative theory of "counter-hegemonic globalization" directly attacks the core neoliberal principle of guiding market forces and unrestricted transnational capital flows. ${ }^{44}$ However, although they challenge basic assumptions about globalization, Evans's

39. Id. (noting how, in spite of these legislative efforts, more tax havens have come into existence).

40. See Adam H. Rosenzweig, Why Are There Tax Havens?, 52 WM. \& MaRY L. REv. 923, 927 (2010) (noting that tax havens continue to flourish despite the efforts of the OECD).

41. See, e.g., Beckett G. Cantley, The Cure Causes New Symptoms: Capital Control Effects of Tax Enforcement, Gold Regulation, and Retirement Reform, 7 S.C.J. INT'L L. \& BUS. 75, 97-98 (2010) (arguing that the tax haven regulations imposed by the HIRE Act represent capital controls that will discourage U.S. investment abroad); Andrew P. Morriss, Changing the Rules of the Game: Offshore Financial Centers, Regulatory Competition \& Financial Crisis, 15 NEXUS J. OP. 15, 17-18 (2009/2010) (arguing that tax havens play an important role in directing efficient use of capital and in compelling state governments to cede economic control to market forces); Daniel L. Hess, Change is Good, Dollars are Better: Prospects for International Tax Reform, 20 J. INT'L TAX'N 1, 1, 5 (2009) (arguing that the current administration's efforts at tax haven reform will place on an unreasonable strain on U.S. business interests abroad); Kimberly Carlson, When Cows Have Wings: An Analysis of the OECD's Tax Haven Work as It Relates to Globalization, Sovereignty and Privacy, 35 J. MARSHALL L. REv 163, 172-75 (2002) (arguing that the OECD's efforts at multilateral tax haven regulation conflicted with the established principles of globalization).

42. Peter Evans, Is an Alternative Globalization Possible?, 36 PoL. \& Soc’Y 271, 272 (2008).

43. Harold Koh, Transnational Legal Process, 75 NEB. L. REv. 181, 181 (1996).

44. Evans, supra note 42 , at 272. 
assertions are not entirely novel; rather, he bases much of his argument on Karl Polanyi's argument that "no socio-political order whose priority is to give pre-eminence to the self-regulating market is sustainable." 45 While acknowledging that the current system of globalization features many elements inconsistent with the theoretical principles of neoliberal globalization-such as "the persistent imposition of rules and resource allocation based on the political interests of the powerful and despite the growing importance of neo-mercantilist rivalries among major powers"-Evans asserts that the "dominant elites" remain ideologically committed to the neoliberal theory, thus rendering the current system prey to the unsustainability Polanyi described. ${ }^{46}$ Evans argues that the neoliberal theory of globalization has failed in two key ways:

The first is failure to construct social mechanisms for doing what markets are inherently incapable of doingprotecting people and nature from inordinate manmade risks and from being treated as "externalities." The second is inability to govern markets and discipline capital so that capitalists themselves are protected from the potential chaos of unregulated markets and are compelled by competitive pressures to perform their Smithian role of "revolutionizing the means of production." 47

The first failure of neoliberal globalization that Evan discusses focuses on the inability of the theory to protect social rather than economic benefits. ${ }^{48}$ Evans begins with the assumption that "nature and markets generate risks" and that society, including both the public and the private sector, has traditionally born the burden of guarding against these risks. ${ }^{49}$ However, Evans argues that neoliberal globalization, with its dismissal of state authority in favor of the rule of market forces, has shifted these risks "from governments and corporations to individuals with far less capacity to bear them." 50 This, in turn, has led to a decrease in the amount of social protection afforded individuals, particularly in the realm of collective goods such as health care and environmental protection. ${ }^{51}$ Evans argues that, rather than treating
45. Id.
46. Id. at 276.
47. Id. at 277 .
48. Id.
49. Id.
50. Id.
51. Id. 
these collective goods as "fundamental components of social protection" that generate "positive spillovers," neoliberal globalization treats them merely as another "commodity," thus leading to an under-allocation of resources toward these goods. ${ }^{52}$ Furthermore, the negative effects resulting from the under-protection of these collective goods have only increased as development and population have increased. ${ }^{53}$ In essence, Evans argues that the neoliberal system of globalization and its enforcement of "the untrammeled reign of the self-regulated market" fail to recognize the value of many social goods and the harm their inadequate protection can cause. ${ }^{54}$

Evans also criticizes neoliberalism's overemphasis on the value of technological capital at the expense of human capital. ${ }^{55}$ Specifically, Evans argues that, to protect the wealth and power provided by the technological advances it has helped to create, neoliberal globalization has permitted elites within the system to enforce monopolistic interests in the most profitable technologies. ${ }^{56}$ Consequently, this enforcement of monopoly interests over "intangible" technological capital has kept this resource in the hands of only a chosen few and out of the hands of actors rich in human capital, creating an imbalance in who actually realizes the benefits of the self-regulating market for which the neoliberal system of globalization does not account. ${ }^{57}$ Furthermore, contrary to the claims of the neoliberal theory, Evans asserts that protection of monopolies on technology actually hinders technological progress, particularly when it comes to the development of technologies that are key to protecting collective social goods such as drug and medical technologies. ${ }^{58}$

Compounding these shortcomings is Evans's second great criticism of neoliberal globalization: the lack of adequate governance of markets and capital flows. ${ }^{59}$ As mentioned above, Evans asserts that neoliberal globalization's commitment to eliminating regulation in favor of a selfregulating market has undermined the ability of state actors to provide

52. $I d$.

53. See id. at 277.78 (noting, for example, that inadequate protection of health care has a significantly greater impact in a densely populated urban state today than in a sparsely populated agrarian one a century ago).

54. Id. at 278 .

55. Id.

56. Id. (noting, for example, the sole control exercised by Microsoft over Windows software technology or by multinational pharmaceutical companies over drug formulas).

57. $I d$. at 278-79.

58. Id. at 279 (noting, for example, that the cost of HIV/AIDS drugs decreased by up to $98 \%$ after the monopoly rights of pharmaceutical companies expired).

59. Id. at 280 . 
adequate protection of social-collective goods.60 However, Evans's argument goes beyond this point to assert that economic growth has so far outstripped any effective regulatory mechanisms, whether national or global, that the economic as well as social health of the system has begun to suffer. ${ }^{61}$ As to how adherence to the neoliberal theory could lead to the opposite of the intended result, Evans provides a succinct answer: "Genuine ideological conviction that regulation reduces efficiency, combined with short-sighted self-interest in being able to profit from the absence of governance, leaves neo-liberal elites incapable of constructing even the order that they need for their own long-term accumulation of capital."62 Crucial to the subject of this note, Evans points out that the danger of harmful consequences resulting from a lack of adequate governance has proven especially great in the financial sector, where technological advances and the efforts to erode capital controls have caused the growth of transnational capital flows to far outpace any efforts to regulate them. ${ }^{63}$

To conclude, Evans argues that these failures have caused substantial disillusionment with the neoliberal system of globalization in the wake of the recent financial crisis, thus opening the door for an alternative form of globalization to supplant the neoliberal elites (what Evans calls "counter-hegemonic globalization"). ${ }^{64}$ Although Evans admits that he remains unsure as to exactly what form this "counterhegemonic globalization" will take, ${ }^{65}$ the opportunity this shift has presented to challenge accepted globalization norms has already begun to bear fruit, as we shall see later.

\section{B. Transnational Legal Process}

Unlike Evans, Koh does not directly attack the neoliberal system of globalization. However, his theory of "transnational legal process" does run contrary to the principles of neoliberal globalization by asserting that states, along with a variety of other actors, can take action to influence the creation and enforcement of evolving international norms: "Transnational legal process describes the theory and practice of how public and private actors-nation-states, international organizations,

60. Id.

61. See id.

62. Id.

63. Id. (pointing out how the number of global financial crises has increased along with capital flows).

64. Id. at 281.

65. Id. (noting that the new globalization could take a variety of forms, from diversely democratic, to hegemonic, to neo-nationalistic). 
multinational enterprises, nongovernmental organizations, and private individuals-interact in a variety of public and private, domestic and international fora to make, interpret, enforce, and ultimately, internalize rules of transnational law."66

Several factors of Koh's theory will prove relevant to this note's study of tax haven reform. First, Koh asserts the theory is nonstatist, meaning that state actors do not play the only or even the primary role in the creation and enforcement of new international norms. ${ }^{67}$ At first glance, this element may appear to support the neoliberal theory of globalization. However, Koh's theory remains distinct from neoliberal theory in that, although it denies state actors the exclusive role in crafting and enforcing international norms, it still allows for a substantial role for states alongside a variety of other nonstate actors. ${ }^{68}$ This stands in contrast to the neoliberal theory's relegation of state actors to the role of mere puppets of an all-powerful market economy. ${ }^{69}$

Second, the transnational legal process is dynamic and constantly evolving; under this process, "[t]ransnational law transforms, mutates, and percolates up and down, from the public to the private, from the domestic to the international level and back down again."70 The cyclical nature of this evolutionary process also sets Koh's theory apart from neoliberal globalization. Although neoliberal theory clearly allows for development and evolution, it views the process as one in which the market directs and enforces change rather than one where input from a variety of actors at all levels can drive change. ${ }^{71}$

Third, the transnational legal process is normative, meaning that the interaction of actors of all kinds at both the domestic and transnational level leads to the creation, interpretation, and enforcement of new transnational legal norms. ${ }^{72}$ This point provides the crux of Koh's argument against the neoliberal view, because it allows a variety of state and nonstate actors to play an active, positive role in shaping the course of globalization.

Thus, although Koh put forth his theory several years before the recent financial crisis, these three elements of transnational legal process and their deviation from the core principles of the neoliberal theory of globalization make them particularly relevant to our

\footnotetext{
66. Koh, supra note 43 , at $183-84$.

67. See id. at 184 .

68. See id.

69. See Strange, supra note 22 , at 133 .

70. See Koh, supra note 43 , at 184 .

71. See Strange, supra note 22, at 132-33.

72. See Koh, supra note 43 , at 184 .
} 
examination of the globalization shift embodied in the recent efforts at tax haven reform.

\section{EvidENCE OF CHANGING VIEWS OF GLOBALIZATION IN TAX HAVEN REFORM}

The scholarship and legislative history surrounding the recent efforts at tax haven reform provide an excellent case study of the limited shift away from the neoliberal view of globalization brought on by the recent financial crisis. Of course, real-world actions will rarely, if ever, perfectly adhere to theory, and this case proves no exception. To begin with, nowhere in the legislative history surrounding both FATCA and the Stop Tax Haven Abuse Act does explicit mention of any globalization theory appear. Not surprisingly, the respective legislative histories of each Act expressly point to much more politically relevant motivations such as increasing tax revenue and decreasing the budget deficit. ${ }^{73}$

Furthermore, the recent efforts at tax haven reform represent a mere limited shift away from the traditional neoliberal model, not an absolute paradigm change. It remains worth remembering that, as of writing of this note, the Stop Tax Haven Abuse Act has not yet passed despite repeated introductions in Congress. ${ }^{74}$ This fact alone indicates that members of the government (and possibly the business interests that lobby them) remain uncomfortable with threatening the perceived economic benefits of transnational capital flows with legislation targeting tax havens. Indeed, some of the legislative history surrounding the reform efforts explicitly expresses a desire to protect positive aspects of the neoliberal globalization regime. ${ }^{75}$

However, although the recent tax haven reform efforts signal nothing as dramatic as the death of the neoliberal globalization regime and the rise of a new globalization order, they do provide evidence of a

73. See, e.g., 153 CoNG. REC. S6221 (daily ed. May 17, 2007) (statement of Sen. Kent Conrad) (asserting that approximately $\$ 100$ billion in tax revenue is lost annually due to use of offshore tax havens); 153 CONG. REC. S3688 (daily ed. March 23, 2007) (statement of Sen. Carl Levin) (arguing that tax haven reform can increase tax revenue and decrease the annual budget deficit).

74. See S. 681, supra note 5; H.R. 2136, supra note 5; S. 506, supra note 6; H.R. 1265, supra note 6; S. 1346, supra note 7; H.R. 2669, supra note 7; H.R. 1554, supra note 8; S. 1533, supra note 8; H.R. 3666, supra note 8.

75. See 158 CoNG. REC. S5104 (daily ed. July 18, 2012) (statement of Sen. Joseph Durbin) (asserting that the tax haven reform efforts he supports do nothing to "impinge[ on any individual's right to hold financial interests anywhere in the world"); 154 Cong. Rec. S2098 (daily ed. March 13, 2008) (statement of Sen. Carl Levin) (distinguishing between abusive tax shelters and congressionally sanctioned tax shelters). 
limited but significant shift away from the core principles of neoliberal globalization theory. This evidence appears in both (a) the statements and actions of the U.S. government, foreign governments, and private actors surrounding the reform efforts and (b) the legal scholarship analyzing the reform efforts.

\section{A. Evidence of the Shift in the Statements and Actions of Governments and Private Actors}

Evidence of this shift in the view of globalization and the state's role in it can be seen first and foremost in the statements and actions of the U.S. government, foreign governments, and private actors. To begin with, while the legislative history surrounding FATCA and the Stop Tax Haven Abuse Act never explicitly references a new globalization theory, it does provide evidence of both a recognition of the negative consequences of unfettered transnational capital flows and a belief in the ability of the state to play a positive, active role in correcting those negative effects.

First, the legislative history surrounding the acts paints a decidedly negative picture of tax havens and their use by U.S. individuals and corporations to decrease the amount of taxes paid to the U.S. government; such activity is labeled as "offshore trickery," 76 "monkey business,"77 "a giant shell game," and "an enormous tax scam." 78 Those who engage in such activity are called "tax dodgers"79 and "tax cheats" who use "high-priced accountants, lawyers, and banks" to transfer a large portion of their U.S. tax burden "onto the backs of honest taxpayers." 80 Even more significantly, the legislative history accuses these tax havens and those who make use of them of "undermining the integrity of our tax system"81 and driving a financial "race to the bottom." 82 Although one could attribute some of the severity of this language to mere political verbosity, one cannot ignore the fact that such negative portrayals of what can only be described as a form of transnational capital flow conflict with the previously accepted sunny picture painted by neoliberal globalization theory. Furthermore, the contemporaneous acknowledgement by conservative economic minds of the market's failure to effectively regulate capital flows suggests this

76. 157 CONG. REC. S4518 (daily ed. July 12, 2011) (statement of Sen. Carl Levin).

77. 153 ConG. REC. $\$ 3660$ (daily ed. March 23, 2007) (statement of Sen. Kent Conrad).

78. 153 CONG. REC. S6221, supra note 73 (statement of Sen. Kent Conrad).

79. 157 CoNG. REC. S4519 (daily ed. July 12, 2011) (statement of Sen. Carl Levin).

80. 154 CONG. REC. S2098, supra note 75 (statement of Sen. Carl Levin).

81. Id.

82. 158 CONG. REC. H5286 (daily ed. July 25, 2012) (statement of Rep. Barney Frank). 
language amounts to more than mere liberal rhetoric. ${ }^{83}$ Rather, by accusing tax havens of undermining the strength of the U.S. legal system and decreasing the amount of tax revenue available for funding government programs, these statements echo Evan's criticism that strict adherence to the self-regulating market of neoliberal globalization can harm social goods. ${ }^{84}$

However, evidence provided by the legislative history challenges not just the sanctity of transnational capital flows promoted in neoliberal thinking but the role of the state in influencing those flows as well. Unlike the almost fatalistic view of the decay of state power in the wake of market forces embraced by the neoliberal theory, ${ }^{85}$ the statements found in the legislative history argue that the United States can and should take action to regulate these capital flows. ${ }^{86}$ Indeed, the statements in the legislative history come close to explicitly rejecting neoliberal theory by chiding members of Congress for tacitly accepting the ongoing use of tax havens in failing to take regulatory action against them ${ }^{87}$ and by refusing to accept a "philosophy" that requires the United States to "match other countries in an absence of rules." 88 Such statements indicate no wringing of the hands and no bowing to the rule of the market; rather, they assert an active, positive role for the state in regulating and shaping the path of globalization as envisioned in Koh's transnational legal theory. ${ }^{89}$

The evidence of this theoretical shift is not limited to the statements and actions of the U.S. government, however; several other states have taken steps that indicate their concurrence with the views underlying these tax haven reform efforts. For example, France, Germany, Italy, Spain, and the United Kingdom have worked with the United States to try to establish a framework for the information sharing and disclosure

83. See, e.g., Edmund L. Andrews, Greenspan Concedes Error on Regulation, N.Y. TIMES, Oct. 24, 2008, at B1, available at http://www.nytimes.com/2008/10/24/business/ economy/24panel.html?_r=0 ("[A] humbled Mr. Greenspan admitted that he had put too much faith in the self-correcting power of free markets ....").

84. See Evans, supra note 42 , at 278.

85. See Strange, supra note 22, at 132-33.

86. See 157 ConG. REC. S4519, supra note 79 (statement of Sen. Carl Levin); 154 CONG. REC. S2098, supra note 75 (statement of Sen. Carl Levin); 153 CoNG. REC. S6221, supra note 73 (statement of Sen. Kent Conrad); 153 CoNG. REC. S3660, supra note 77 (statement of Sen. Kent Conrad).

87. See ConG. REC. S6221, supra note 73 (statement of Sen. Kent Conrad) ("Shame on us if we are being fooled. But currently, we are.")

88. 158 CONG. REC. H5286, supra note 82 (statement of Rep. Barney Frank).

89. See Koh, supra note 43 , at 184 . 
mandated under FATCA. ${ }^{90}$ Perhaps even more telling, Liechtenstein, a well-known tax haven, has indicated a willingness to adopt international standards of information disclosure to prevent misuse of its secretive banking services. ${ }^{91}$

Evidence of these changing views comes from beyond the state level as well; many private actors have indicated a willingness to embrace greater regulation of capital flows. One of the most notable examples is Swiss banking giant UBS, which agreed to disclose information on and to close the accounts of several U.S. clients in 2009.92 UBS does not stand alone among private actors in taking steps to comply with recent tax haven reform efforts; the IRS has received "well over" 7,500 applications for FATCA's voluntary offshore disclosure program. ${ }^{93}$

These actions by private actors, along with those of foreign state actors discussed above, further conform to Koh's theory of transnational legal process: not only do they provide broad evidence of state and nonstate actors playing an active role in shaping transnational norms, ${ }^{94}$ but they also provides examples of the dynamic and normative power of their interactions.95 One can trace the path of norm creation, interpretation, and enforcement from the beginning of reform efforts at the state level in the U.S., to interpretation of what those reform efforts will mean at the transnational level, to further interpretation and the beginnings of adoption and enforcement of some new tax haven norms at both the national and the transnational level by both state and nonstate actors. Thus, the statements and actions of the U.S. government, foreign governments, and private actors surrounding these two pieces of legislation and related tax haven reform efforts provide significant evidence of a limited shift away from the neoliberal model of globalization to a model that allows for some regulation of capital flows and envisions a significant role for state and nonstate actors in crafting those regulatory norms.

90. See Bruce Zagaris, Bilateral Agreement Alternative to FATCA Implementation Brings New Twist to International Tax Cooperation, 28 INT'L ENFORCEMENT L. REP. 113, 113 (2012).

91. See Spencer, supra note 1, at 56-57.

92. See Bruce Zagaris, Senate Permanent Subcommittee on Investigations Holds Second Hearing on Tax Haven Banks in the UBS Case, 25 INT'L ENFORCEMENT L. REP. 183 (2009).

93. Bruce Zagaris, House Ways \& Means Subcommittee Shows Support for Foreign Bank Account Reporting and Tax Compliance, 26 INT'L ENFoRCEMENT L. REP. 31, 31 (2010).

94. See Koh, supra note 43 , at 184 .

95. See id. 


\section{B. Evidence of the Shift in Legal Scholarship}

Along with the evidence provided by the reform efforts, much of the legal scholarship analyzing those reform efforts also provides evidence of a limited shift in the globalization paradigm. First, many of the articles of legal scholarship critiquing FATCA and the Stop Tax Haven Abuse Act acknowledge that states can and should play an active role in regulating transnational capital flows, even those that oppose the specific methods embodied in these pieces of legislation. ${ }^{96}$ Such acknowledgement means that, while they many disagree on the proper means of regulation, many legal scholars do endorse Koh's argument that state actors can play a positive and active role in creating transnational regulatory norms. ${ }^{97}$

In tandem with this acknowledgment of the ability of states to regulate transnational capital flows, many legal scholars have also acknowledged the potential negative effects of tax havens and the unregulated capital flows. Timothy Addison, for example, argues that allowing the unregulated tax flows that permit the abusive use of tax havens decreases aggregate social welfare by allowing individuals to pay less in taxes than the cost of the public benefits they enjoy. 98 This argument closely mirrors one of Evans's major criticisms of the neoliberal theory of globalization-that it provides inadequate protection of social goods. ${ }^{99}$

Furthermore, several legal scholars have argued that unfettered capital flows have led directly to the proliferation of offshore tax havens. Adam Rosenzweig, for instance, argues that tax havens arise out of what he calls the "capital neutrality paradox." 100 By this he means that, because states have sought to realize the economic benefits of globalization by allowing the free transnational flow of capital and avoiding double taxation (i.e., taxing the same funds twice, abroad and at home) to maintain "capital neutrality," they have unintentionally created the incentives for states to act as tax havens:

The problem is that there is a cost to making capital more mobile in addition to a benefit: the more mobile

96. E.g., Morriss, supra note 41, at 15 ("Even ardent proponents of free markets often concede a significant role for the state in providing the 'rules of the game' for market competition ... "); Cantley, supra note 41, at 108 ("The United States has legitimate articulated reasons for implementing tax haven enforcement overseas ...").

97. See Koh, supra note 43 , at 184 .

98. See Addison, supra note 4, at 708-09.

99. Evans, supra note 42 , at 278 .

100. Rosenzweig, supra note 40 , at $930-31$. 
capital becomes, the more easily countries can use tax incentives to attract such capital. In other words, one country focusing on double taxation relief can make tax competition a cheaper and more readily available instrument for other countries to attract capital. ${ }^{101}$

Although Rosenzweig acknowledges that this causal relationship does not necessarily mean that the negative effects of incentivizing tax havens will outweigh the benefits of capital neutrality, ${ }^{102}$ his argument about the "capital neutrality paradox" conforms to Evan's criticism of the neoliberal theory of globalization. It draws a direct line between the neoliberal adherence to unrestricted capital flows and the decreased aggregate social welfare caused by loss of tax revenue to tax havens.

Finally, some of the legal scholarship on the recent efforts at tax reform echo Koh's theory of transnational legal process by analyzing the ability of state and nonstate actors to craft new transnational tax norms. For example, Allison Christians argues that "tax law emerges and evolves through iterative interactions among politicians, lawmakers, administrators, practitioners, taxpayers, advocates, the media, and academics," and points to how comparison and peer pressure among members of the OECD have influenced their respective tax law regimes. ${ }^{103}$ In tracing the path of tax law formation from the state level; to the transnational level of the OECD; to the state level again as Member States influence, interpret, and internalize new tax norms, Christians's argument almost mirrors Koh's language describing the dynamic process of norm formation. ${ }^{104}$

Thus, legal scholarship analyzing the recent efforts at tax haven reform further reflects the limited shift away from the neoliberal theory of globalization to a new paradigm that recognizes the benefits of capital flow regulation and the ability of both state and nonstate actors to realize it.

101. Id. at 931. See also Addison, supra note 4, at 711 (noting the incentive to offer competitive tax rates as a driving force behind tax haven proliferation); Morriss, supra note 41 , at 18-19 (identifying offering tax shelter services as a means for states to compete for economic investment).

102. See Rosenzweig, supra note 40, at 930-31.

103. Allison Christians, Networks, Norms, and National Tax Policy, 9 Wash. U. Global Stud. L. Rev. 1, 29-32 (2010). See also Morse, supra note 18, at 727-28 (analyzing FATCA in the context of tax norm formation between OECD member states).

104. See Koh, supra note 43 , at 184. 


\section{CONCLUSION}

The recent financial crisis has led to a widespread reexamination of global financial norms, including the transnational free flow of capital. Efforts at tax haven reform, most notably FATCA and the Stop Tax Haven Abuse Act, and the legislative history and legal scholarship surrounding them, provide evidence of a limited shift away from the traditional neoliberal theory of globalization to one that both recognizes the potentially positive benefits of transnational capital regulation and envisions an active role for both state and nonstate actors in creating, adapting, and enforcing those regulations. Time will tell whether this shift will continue or what other areas of globalization it may impact. However, if this alternative thinking about globalization can impact an area of transnational finance as significant as tax havens and a principle of globalization as essential as capital flows, it seems likely that globalization thinking will continue to evolve. 


\section{.}

